\title{
Odkud a kam směřuje venkovní výuka? Historie, současnost a trendy ve venkovní výuce v kontextu vzdělávacích teorií ${ }^{1}$
}

\author{
Karel Nepraš, Renata Šikulová \\ Univerzita J. E. Purkyně v Ústí nad Labem, Pedagogická fakulta, Katedra preprimárního \\ a primárního vzdělávání
}

Redakci zasláno 21. 12. 2020 / upravená verze obdržena 23. 4. 2021 /

/ k uveřejnění přijato 25. 4. 2021

\begin{abstract}
Abstrakt: Venkovní formy výuky se v posledních letech v České republice dostávají do širšího povědomí pedagogické veřejnosti a jsou s rostoucí měrou využívány $\mathrm{v}$ rámci všech úrovní vzdělávání. Postavení české venkovní výuky v této souvislosti zasluhuje zvýšenou pozornost, protože s rostoucím podílem využívání venkovních aktivit se postupně navyšuje i reálný impakt na vzdělávací proces. Venkovní výuka na našich základních školách vychází z tradic vázaných na využívání blízkého okolí školy a školních zahrad a její kořeny sahají do 19. století. V současné době je realizována nejčastěji krátkodobě a spíše občasně. Většina škol má k dispozici školní zahradu a alespoň částečně ji pro venkovní formy výuky využívá. Školy mají ve svých kurikulárních dokumentech zahrnuty exkurze, vycházky, terénní cvičení, školní výlety, sportovní kurzy, případně školy v přírodě, adaptační kurzy a projektovou výuku. Rychle rostoucí vliv na podobu a rozsah venkovní výuky u nás mají v současnosti centra environmentálního vzdělávání, která se zaměřují jak na realizaci konkrétních programů pro školy, tak na vzdělávání a rozvoj pedagogů $\mathrm{v}$ daném segmentu a značně přispívají $\mathrm{k}$ rozšiřování venkovních forem výuky v českém prostředí. $\mathrm{V}$ aktuálně publikovaných metodických dokumentech zaměřených na venkovní výuku majících potenciálně větší dopad na české edukační prostř̌edí je možné identifikovat společné znaky. Konkretizovanější podoba venkovní výuky, ke které metodické materiály vedou, v sobě nese prvky otevřené pedagogiky ve smyslu posilování role učitele jako partnera a průvodce žáka aktivním učením a zdůrazňuje nutnost aktivní role žáka při edukačním procesu. Charakteristické jsou konstruktivistické rámce a badatelsky orientované přístupy, zdůrazňovány jsou př́nosy kooperativního učení a soulad s pedagogikami probouzejícími žákovo uvědomění odpovědnosti za životní prostředí. Aktuální pojetí venkovních forem výuky do značné míry naplňují koncepty holistického pojetí výuky.
\end{abstract}

Klíčová slova: venkovní výuka, terénní výuka, vzdělávací teorie

1 Článek vznikl v souvislosti s projektem Postoje českých učitelů $k$ venkovní výuce UJEPSGS-2020-43-004-1 a byl podpořen grantem v rámci studentské grantové soutěže na Univerzitě Jana Evangelisty Purkyně v Ústí nad Labem. 
Venkovní výuka prochází v současném českém školství dynamickým vývojem. Při něm dochází k nastolování nových pojetí, která, pokud u nás výjimečně byla $\mathrm{v}$ minulosti $\mathrm{v}$ zárodcích přítomná, stála na okraji pozornosti. Nyní je oproti tomu možné hovořit v rámci formálního vzdělávání o prokazatelné progresi zájmu o venkovní formy výuky od preprimárního vzdělávání až po univerzitní studia.

Na příkladu výrazného navyšování počtu lesních mateřských škol v poslední dekádě je dobře dokumentovatelný rostoucí zájem o venkovní aktivity v předškolním prostředí (Lesnims.cz, 2019). Měnící se úhel pohledu na venkovní aktivity na základní škole je patrný z velké poptávky po projektových aktivitách související s pobytem dětí venku. V rámci online kurzů venkovní výuky, které byly týmem Učíme se venku realizovány během jednoho roku od prosince 2019 do prosince 2020, se podařilo zapojit 3200 účastníků (Ucimesevenku.cz, 2020). K tomu se i na úrovni základního školství objevují pokusy o navázání na lesní pedagogiku v předškolním období a výrazný rozvoj zaznamenávají prvky př́rodních zahrad na školních pozemcích. Veřejný zájem a zároveň masivní poptávku po progresi v segmentu venkovní výuky dokumentuje nedávná dotační výzva (Ministerstvo životního prostředí, 2020), ve které ani alokovaných 250 mil. Kč, určených na rozvoj přírodních zahrad ve školních zařízeních i v neziskových zařízeních zaměřených na EVVO, nestačilo k uspokojení všech zájemců. Také na vysokých školách získává venkovní výuka stále větší pozornost, což je patrné na příkladu projektu Systém terénní výuky pro základní školy realizovaného na Pedagogické fakultě Masarykovy univerzity v Brně (Masarykova univerzita, 2020).

Není bez zajímavosti, že si relativní pozornost získal citát vycházející z Velké didaktiky J. A. Komenského z roku 1657 (Komenský, 1930): „Lidé mají se učiti, pokud nejvíce možno, ne nabývati rozumu z knih, nýbrž z nebe, země, dubů a buků, tj. znáti a zkoumati věci samy, a ne pouze cizí pozorování a doklady o věcech." Komenského apel je opakovaně využíván pro motivační úvody publikací souvisejících s venkovní výukou dětí (Daniš, 2018; Kovářová, 2014; Morkes, 2010; Špačková, 2013). Je v tom dobře patrná snaha o zdůraznění vnímání širokých možností venkovní výuky, respektive výuky v kontaktu s prŕrodou. Citát nyní funguje jako obhajoba venkovní výuky jakožto formy smysluplné, hodné pozornosti a dávno prověřené. Zároveň může vyjadřovat také určitou snahu o navázání na dobrou praxi, kterou podle Morkese (2010, s. 1) čeští učitelé odvozovali z Komenského pozitivního vztahu k přírodě 
během 19. století, když se obsahově a organizačně na našem území konstituoval školský systém.

Postavení české venkovní výuky v této souvislosti zasluhuje zvýšenou pozornost, protože s rostoucím podílem využívání venkovních aktivit se postupně navyšuje i reálný impakt na vzdělávací proces. Je potom na místě popsat historická východiska, na kterých dnešní venkovní výuka staví, zdokumentovat současné postavení venkovní výuky v České republice a nastínit aktuální směrování venkovní výuky v kontextu vzdělávacích teorií. Právě to jsou cíle, které si klade předkládaný př́íspěvek.

\section{$1 \quad$ Pojetí venkovní výuky}

V následujícím textu je přednostně využíván termín venkovní výuka a další odvozené tvary odkazující na anglické termíny outdoor learning, outdoor education nebo fieldwork (Dillon et al., 2006; Lambert \& Reiss, 2014; Miller, 2017; Rickinson et al., 2004; a řada dalších). V některých českých publikacích je ve srovnatelném významu pojem venkovní výuka zastupován termínem terénní výuka (Činčera \& Holec, 2016; Svobodová et al., 2019b; aj.). Dalšími používanými tvary výše zmíněných hlavních pojmů jsou například učení venku, učení venku v přirodě, venkovní učení, venkovní vzdělávání, terénní vyučování, výuka ve venkovním prostředí apod. (Činčera et al., 2019; Daniš, 2018).

Venkovní výuka představuje především organizační formu spojenou s pobytem žáků a studentů ve venkovním prostředí, at' už se jedná o školní zahradu, blízké okolí místa školy nebo vzdálené krajiny na školách v přírodě či zážitkových akcích. Podle Rickinsona a kol. (2004) zahrnuje pojem venkovní výuka v obecném pojetí nejrůznější typy organizovaného učebního procesu realizovaného ve venkovním prostředí. V českém kontextu Hofmann a kol. (2011, s. 310-311) definují terénní výuku jako „komplexní výukovou formu, která v sobě zahrnuje progresivní vyučovací metody (pozorování, pokus, laboratorní činnosti, projektovou metodu, kooperativní metody, metody zážitkové pedagogiky) a různé organizační formy výuky, jako jsou terénní cvičení, výcvikové kurzy, exkurze, tematické školní výlety, expedice“. Činčera a Holec (2016) pak pod pojem venkovní výuka zahrnují školní a mimoškolní vzdělávací aktivity na školních zahradách a pozemcích, adaptační kurzy, školy v př́írodě a další programy zaměřené na rozvoj vztahů ve třídě, místně zakotvené učení a komunitně orientované projekty, terénní exkurze a programy organizované školou a krátkodobé a pobytové programy organizované externími 
subjekty. Oost a kol. (2011) a Lambert a Balderstone (2010) venkovní výuku chápou jako realizaci výukových aktivit ve venkovním prostředí a také jako silnou výukovou strategii, která umožňuje komplexněji chápat reálný svět.

V dalším textu jsou přednostně akcentovány aspekty venkovní výuky spojené s učebním procesem ve formálním vzdělávání, především pak na úrovni základní školy.

\section{Historie venkovní výuky v českých zemích}

Nejstarší etapa venkovní výuky v českých zemích je spjatá s existencí školních zahrad a je možné ji dohledat již v prvopočátcích povinné školní docházky u nás. Dlouhou historii školních zahrad na našem území shrnuje Morkes (2010). Školní zahrady začaly být systematičtěji zřizovány po vydání V̌̌eobecného školního řádu Marií Terezií v roce 1774 . V prvních desetiletích 19. století ovšem ještě fungovaly zejména jako hospodářské zázemí a částečný zdroj obživy samotných učitelů, ve kterém zároveň přirozeně probíhala výuka. $\mathrm{K}$ významným propagátorům sepětí školy s př́rodou patřil $v$ té době významný český filozof a pedagog Vincenc Zahradník (1790-1836). První plánovitě a koncepčně založená školní zahrada byla vybudována v rámci pokrokového soukromého vzdělávacího ústavu Budeč v Praze ve 40. letech 19. století Karlem Slavojem Amerlingem (1807-1884). V roce 1869 byla tzv. Hasnerovým zákonem zavedena povinná osmiletá školní docházka pro všechny děti a stejný dokument také stanovoval ve venkovských školách povinnost zřízení učitelské zahrady a pozemku pro výuku dětí. V období první republiky po roce 1918 se již školní zahrady staly trvale etablovanou součástí školního zázemí a byly výslovně jmenovány ve výčtech příslušenství, které má každá škola mít. Školní zahrady fungovaly jako zásadní prostor pro praktickou činnost dětí, budování jejich vztahu k př́rodě, seznamování se zemědělstvím a navazujícími praktickými činnostmi. Obecněji byly školní zahrady v této době již vnímány jako prostor, ve kterém žáci mohou vlastními silami dosáhnout hmatatelného výsledku své práce při prohlubování pochopení souvisejících přírodních procesů (Morkes, 2010).

Jančaříková (2007) uvádí, že cílené venkovní vyučování bylo realizováno v českých zemích již v 70. letech 19. století. Ve stejné době také Vaníček (1875) publikoval doporučení upozorňující na tehdejší ministerský výnos a zároveň se odkazující ke Komenského didaktice, v němž doporučuje pedagogům co nejčastější vycházení s žáky do venkovního prostředí. Rohlena 
(1928) propagoval myšlenku lesních škol a publikoval mimo jiné i nerealizovaný plán na zř́izení lesní školy v Kostelci nad Orlicí z roku 1907. Klíčovou postavou venkovní výuky v období první republiky se stal Eduard Štorch (1878-1956), který po zkušenostech s neradostnými životními podmínkami dětí na Mostecku, kde po určitou dobu působil, rozvinul myšlenku spojení výuky s pobytem dětí v př́rodě. $V$ pražské Libni vybudoval a na vlastní náklady v letech 1926-1930 provozoval Dětskou farmu, kde děti během vyučování žily a volně pracovaly v přírodě. Přitom si vedl pečlivé záznamy, ve kterých zachytil upevnění zdraví dětí, zvýšení sounáležitosti dětí napříč třídami, zvýšené sociální cítění, seberegulaci skupin, rozvoj pracovních návyků aj. (Štorch, 1929).

Období po druhé světové válce bylo zásadně poznamenáno nastolením jednotné školské soustavy. Po roce 1948 komunistické vlády cíleně potlačily prvorepublikovou diverzitu pedagogických přístupů a celému československému školství vtiskly sjednocený řád. Při vzdělávání budoucích pedagogů byl kladen důraz na ideologický profil, který měl být v souladu s nastoleným kurzem vedoucí strany (Morkes, 2002; Předotová, 2014). V důsledku takového stavu nutně docházelo také $\mathrm{k}$ unifikaci venkovních aktivit v rámci vzdělávání na školách. Ty tak nejčastěji zahrnovaly venkovní realizaci předmětů spojovaných s pobytem venku z praktických důvodů (pěstitelské práce, tělesná výchova), zatímco širší využívání venkovních forem napříč vzděláváním se dělo velmi vzácně, a to především díky aktivitám nadšených učitelů.

Teprve od roku 1990 se v souvislosti s politickými změnami obnovuje ve školství a v navazujících vzdělávacích aktivitách diverzita, která vede k postupnému rozvoji a využívání různorodějších venkovních aktivit ve výuce.

\section{Současná podoba venkovní výuky}

V současnosti se v českém prostředí setkáváme s prvky venkovní výuky v naprosté většině škol od preprimárního až po univerzitní vzdělávání (Hofmann et al., 2009; Chmelová et al., 2019; Ministerstvo školství, mládeže a tělovýchovy, 2018; Svobodová, 2019a; aj.). Jejich podoba a rozsah jsou ovšem velmi rozdílné v závislosti na typu a zaměření školy, stejně jako věku edukantů. $S$ ohledem na širokou paletu př́ístupů, které venkovní výuka nabízí, není v počátku vyloučen žádný specifický výchovně-vzdělávací akcent. Teprve koncepce vzdělávání $\mathrm{v}$ pojetí každé školy konkretizuje formy venkovního učení, i tak ovšem do značné míry podléhají venkovní aktivity přístupu 
jednotlivých učitelů a podrobněji v rámci školních vzdělávacích programů nebývají rozpracovány (Svobodová et al., 2019a, s. 113-114).

Podrobnějších studií, které by zkoumaly dílčí aspekty venkovní výuky ve zdejších reáliích, je málo. Některé obecněji platné výstupy, například benefity venkovního vzdělávání nebo doporučení efektivních forem a metod výuky, je do jisté míry možné přebírat ze zahraničních publikací (Cottrell \& Cottrell, 2020; Rickinson et al., 2004; apod.). Samotný rozsah a struktura venkovního vzdělávání u nás jsou ovšem tímto způsobem nepostižitelné, a k jejich popisu je tak možné využít pouze extrapolace odvozené z útržkovitých indicií, které máme $\mathrm{k}$ dispozici. Řada aspektů venkovní výuky v České republice na korektní zpracování zatím čeká.

Venkovní výuka se s ohledem na její komplexní a průřezový charakter prolíná celou řadou učebních stylů a pojetí. V závislosti na konkrétním tématu a cíli venkovní výuky se mohou stř́ídat nejrůznější organizační formy výuky od individuálních přes skupinové, kooperativní a projektové až po hromadnou výuku (Václavík, 2002). Tradičnější pojetí venkovní výuky spočívalo často $\mathrm{v}$ realizaci hromadných exkurzí, výletů, případně občasných společných návštěv zázemí nebo okolí školy při výuce některých obvyklých předmětů, jako jsou pěstitelské práce, tělesná výchova nebo prrírodopis. Současný směr venkovní výuky u nás je do jisté míry spjatý s rostoucím akcentem na některé prvky personalistických, sociokognitivních a sociálních teorií vzdělávání.

Prozatím nejucelenější shrnutí dostupných poznatků o české venkovní výuce poskytli Činčera a Holec (2016), kteří se v rámci komplexnější studie věnovali pětici okruhů: 1. Školní zahrady a využití školních pozemků, 2. Adaptační kurzy, školy v přírodě a další programy zaměřené na rozvoj vztahů ve třídě, 3. Místně zakotvené učení a komunitně orientované projekty, 4. Přírodovědně zaměřené terénní exkurze a programy organizované školou, 5. Krátkodobé a pobytové programy organizované externími subjekty. Na základě dostupných studií Činčera a Holec vyhodnotili dostupné informace jednotlivých okruhů činnosti v oblasti venkovní výuky a upozornili na bariéry, na které implementace venkovní výuky může ve školním prostředí narážet. Podle Činčery a Holce (2016, s. 1) v českém prostředí zatím schází „studie, které by se terénní výuce systematicky věnovaly s důrazem na zhodnocení možných přínosů pro kognitivní, afektivní a psychomotorický vývoj žáka“. 
Komparace ukotvení terénní výuky ve školních vzdělávacích programech a její pojetí v modelových základních školách (Svobodová et al., 2019a) přibližuje aktuální postavení venkovní výuky ve školních kurikulárních dokumentech. Jedná se v tomto kontextu o ojedinělou analýzu, která umožňuje podrobněji nahlédnout formální rámec recentního pojetí české venkovní výuky. Venkovní formy výuky jsou přímo nebo nepřímo zmiňovány ve všech analyzovaných školních kurikulárních dokumentech. Nejčastějšími typy venkovní výuky identifikovanými ve školních vzdělávacích programech jsou exkurze, vycházka, terénní cvičení, školní výlet, sportovní kurz a další sportovní aktivity. $Z$ analýzy ovšem nevyplývají konkrétnější strategie využívané v souvislosti s venkovní výukou.

Svobodová a kol. (2019a) klasifikují tři kategorie venkovních forem výuky podle časového trvání jejich realizace. Za krátkodobou terénní výuku považují aktivity trvající do dvou vyučovacích hodin, střednědobé jsou celodenní aktivity, projekty, výlety, exkurze apod. a jako dlouhodobé označují vícedenní akce zahrnující např́íklad komplexnější projektovou výuku ve venkovním prostředí nebo pobytové akce spojené s přespáváním mimo domov.

Pokud se zabýváme už základní otázkou četnosti využívání venkovních forem výuky u nás, narážíme na malé množství dobrých dat, která by nám pomohla tuto neznámou podrobněji odhalit. Svobodová a kol. (2019a) zjistili na základě analýzy školních vzdělávacích programů padesáti škol z jihočeského a jihomoravského kraje, že je terénní výuka hodně zastoupená ve $24 \%$, středně zastoupená v $36 \%$ a málo zastoupena ve $40 \%$ ze studovaných dokumentů. $\mathrm{V}$ rámci dotazníkových šetření mezi 120 vyučujícími na 1 . stupni základní školy (Nepraš, 2020) bylo zjištěno, že častěji a pravidelněji venku učí zhruba třetina z nich, alespoň občas potom zhruba tři čtvrtiny učitelek a učitelů. Zároveň ze stejného šetření vyplynulo, že preferovaná frekvence je výrazně vyšší a častěji by chtělo učit venku téměř 80 \% z dotazovaných.

Baueršímová (2007) shrnuje výsledky celorepublikového průzkumu stavu školních zahrad při základních školách České republiky v roce 2007. V rámci dotazníkového šetření se podařilo získat údaje ze 486 z celkového počtu 4253 základních škol v ČR (12,76\%). Bylo zjištěno, že školní zahradou disponuje 80,5 \% škol. Naprostá většina (97 \%) škol vlastnících školní zahradu ji využívá k výuce alespoň jednoho předmětu. Nejčastěji je zahrada využívána v rámci vzdělávacích oblastí člověk a svět práce $(88,5 \%)$, člověk a př́roda (64,7 \%), člověk a zdraví $(60,6 \%)$, člověk a jeho svět $(58,6 \%)$, 
umění a kultura (54 \%) a při řešení průřezových témat $(63,9 \%)$. Z dalších aktivit školy nejčastěji školní zahrady využívají pro potřeby školní družiny (76,5\%), k relaxaci dětí o přestávce $(63,2 \%)$, v rámci činnosti zájmových útvarů $(56,5 \%)$ a při projektových dnech a týdnech $(54,2 \%)$. Více než dvě třetiny škol využívají školní zahrady pro pěstování květin, ovoce, zeleniny a jako trávník, respektive park, který je místem pro hry a pohybové aktivity. Zhruba třetina (34\%) škol využívá ve školních zahradách ukázky biotopů pro výuku biologie a ekologie, ale pouhá $4 \%$ škol pak pro umístění chovatelských zařízení.

Vácha (2015) analyzoval didaktické využívání školních zahrad v primárním vzdělávání na širokém vzorku 119 škol z České republiky. Zjistil, že z uvedeného počtu $72 \%$ disponuje školní zahradou. Podle $66 \%$ pedagogů je školní zahrada ideálním prostorem pro doplnění a obohacení konvenční výuky, 19 \% vyučujících v zahradách potenciál nevidí a 15 \% si po zvážení přínosů a rizik implementací školních zahrad do výuky není jisto. Ve vybavení školních zahrad, podle Váchy, stále převažují prvky spojené s výukou pěstitelských prací, postupně však dochází k přeměně a doplňování interdisciplinárních prvků. Školní zahrady jsou nejčastěji využívány v rámci vzdělávacích oblastí člověk a svět práce (výroba hmyzího hotelu, krmítka, ptačích budek, výsadba a sklizeň plodin), člověk a jeho svět (inventarizační výzkum a pozorování různých stanovišt', determinace organismů, pozorování proměn přírodnin v závislosti na ročním období aj.), člověk a zdraví (pohybové aktivity, pěstování bylin a jejich následné využití, zdravá výživa). Téměř polovina zúčastněných základních škol (46 \%) má pro výuku na školní zahradě zakotvenou pevnou časovou dotaci. Časová dotace obecně stoupá s ročníkem docházky. Ze 44 studentek učitelství, které Vácha také do výzkumu záměrně zařadil, jich $45 \%$ uvedlo, že by školní zahradu do vyučování vůbec nezahrnulo. Jako hlavní důvody přitom uvádí neoblibu pěstitelských prací během školní docházky, př́lišnou časovou náročnost, nedostatečné materiální zabezpečení zahrad a absenci tematicky zaměřeného předmětu v pregraduální přípravě. $35 \%$ studentek naopak vidí ve výuce na školních zahradách př́inos pro žáky primární školy a do vyučování by se zahradu snažilo co nejvíce implementovat.

Chmelová a kol. (2019) analyzovali charakter a využívání středoškolských školních zahrad. Na menším vzorku $(\mathrm{N}=16)$ vysledovali mimo jiné podstatný rozdíl mezi stabilní hodinovou dotací využívání školních zahrad mezi 
zemědělsky a zahradnicky zaměřenými školami (100-120 hodin ročně) na straně jedné a gymnázii a střední zdravotnickou školou (0-2 hodiny ročně) na straně druhé. Ve využívání školních zahrad dominuje zejména realizace praktických a odborně zaměřených předmětů a realizace praxí žáků. V gymnáziích jsou školní zahrady využívány především pro výuku biologie a výtvarné výchovy. Všechny posuzované školní zahrady plní také další funkce, zejména slouží jako místo pro odpočinek studentů, sportovní a pohybové aktivity či jako místo pro akce určené veřejnosti. Nejčastěji zmiňovanými problémy spojenými s využíváním a provozem školních zahrad gymnázií a středních škol a učilišt' jsou z pohledu ředitelů finanční problémy (nutnost získání finančních prostředků na dobudování zahrad z jiných zdrojů) a personální problémy (zajištění odborných vyučujících a technického personálu).

Na zajištění krátkodobých a pobytových programů organizovaných externími subjekty se nejčastěji podílejí centra environmentálního vzdělávání, se kterými spolupracuje téměř 80 \% ze vzorku 645 škol (Činčera et al., 2016). U externích subjektů si školy nejčastěji objednávají krátké několikahodinové výukové programy, pobytové programy si oproti tomu objednávalo pouze 16 \% ze vzorku 165 škol (Činčera \& Havlíček, 2016).

\section{Vliv center environmentálního vzdělávání}

V českém prostředí je $\mathrm{v}$ oblasti venkovní výuky patrný vliv nevládních neziskových organizací zabývajících se environmentálním vzděláváním. Rozšiřující se sít' ekocenter nabízejících terénní programy pro školy zvyšuje sama o sobě impakt na české vzdělávání a svým pojetím kurzů může do jisté míry působit i na participanty. Jako ještě významnější se pak jeví aktuálně realizované projekty spočívající v rozvoji na venkovní výuku zaměřených webových stránek a navazujících aplikací v rámci sociálních sítí, které zasahují v daném segmentu výrazně širší skupinu české pedagogické i nepedagogické veřejnosti než v minulosti.

Aktuálně nejrozsáhlejším českým webovým projektem zaměřeným na venkovní výuku jsou webové stránky Učíme se venku (www.ucimesevenku.cz), které vznikly za účasti organizací TEREZA, Chaloupky a Lipka a podporuje je řada dalších institucí. Stránky jsou zaměřené primárně na realizátory venkovní výuky a jako takové mají podstatný vliv na utváření a směrování přístupů ve venkovní výuce u nás. Tým Učíme se venku eviduje 19000 sledujících 
a 6115 členů facebookové skupiny, 1300 sledujících na Instagramu a 200 zapojených organizací (Ucimesevenku.cz, 2020). Značný a rostoucí impakt mají také další venkovní výukové aktivity výše jmenovaných center environmentálního vzdělávání $\mathrm{s}$ největším vlivem $\mathrm{v}$ rámci segmentu venkovní výuky u nás. Z výročních zpráv za rok 2019 jsou k dispozici konkrétní čísla zachycující dosah těchto aktivit. Lipka odvedla 1157 výukových programů zahrnujících 6112 hodin výuky pro 25836 účastníků (Lipka, 2020). Chaloupky evidují v roce 2019 celkem 222 hodin výuky a 11627 účastníků v rámci jednodenních výukových programů pro školy a 1202 hodin výuky a 7978 „osobodní" v rámci pobytových výukových programů pro školy (Chaloupky, 2020). TEREZA pak v rámci programu Les ve škole eviduje 16320 účastníků ze 408 zapojených skupin, v rámci badatelsky zaměřeného programu GLOBE potom 250 učitelů a 5000 žáků ze 125 škol (TEREZA, 2020b). Kromě podpory škol realizuje program TEREZA Jděte ven zaměřený na rodiny s impaktem 3481 uživatelů webu měsíčně, 5546 sledujících na Facebooku a 1835 členů uzavřené facebookové skupiny (TEREZA, 2020a). Pochopitelně existuje nesrovnatelně širší skupina ekocenter, spolkủ a dalších organizací, které realizují podobné aktivity. Jejich podrobný výčet ovšem není předmětem tohoto pojednání. Vybrané nejvlivnější organizace zaměřené na programy venkovní výuky na tomto místě především ilustrují význam segmentu z hlediska potenciálu působení na českou edukační realitu.

\section{$5 \quad$ Aktuální metodické materiály}

Jedním z hlavních cílů předkládaného pojednání bylo zachycení směru aktuálního vývoje a ukotvení venkovní výuky u nás z pohledu pedagogické teorie. Za tím účelem jsou níže charakterizovány tř̌i aktuální metodické materiály. Výběr materiálů byl podmíněn ambicí širšího impaktu na české edukační prostředí daným významem organizací, které jejich vydání zaštítily (TEREZA, Chaloupky, Lipka, Masarykova univerzita). Zároveň se jedná o materiály, které obsahují konkrétnější metodická doporučení a návody ke stylu realizace venkovní výuky určená pedagogickým pracovníkům, respektive realizátorům venkovní výuky. Dalším kritériem výběru materiálů byla aktuálnost - všechny vybrané dokumenty byly publikovány v roce 2019. Autorské kolektivy popisovaných materiálů se mimoto téměř nepřekrývají.

Nejsou popisovány starší materiály (Hofmann et al., 2009; aj.), protože některá aktuální novější metodická pojetí z nich částečně vychází a dále je 
rozpracovávají. Dále nejsou zařazeny materiály postavené primárně jako soubory konkrétních aktivit ve venkovním prostředí, ale neobsahující podrobnější metodický rámec pro realizátory, úžeji zaměřené regionálně, nebo tematicky specifičtější publikace a také materiály, které jsou s některým z přibližovaných titulů provázány (Činčera et al., 2019; Danišová, 2018, 2019; Green Schoolyards America, 2018; Svobodová et al. 2018; Svobodová et al., 2019a; Veselá et al., 2019; aj.).

Cesta ven, aneb kontinuum pro rozvoj učení venku (Ucimesevenku.cz, 2019) je sebehodnoticí aplikace, která pracuje s konceptem sebehodnocení s využitím mapy učebního pokroku (Kolektiv, 2014; Masters \& Foerster, 1996). V níže popsané verzi byla použita jako sebehodnoticí a motivační nástroj související s online kurzem Učíme se venku realizovaným v prosinci 2019. Věnuje se devíti oblastem: I. Chceme učit venku pravidelně; II. Víme, co vzít ven; III. Učíme venku celý rok; IV. Dáváme venku dětem prostor; V. Známe okolí školy; VI. Podporujeme volný čas a prostor venku; VII. Učíme venku společně s kolegy; VIII. Víme, jak venku hodnotit; IX. Učíme se místem i pro místo. Na šestistupňové škále umožňuje učitelům zařadit se v rámci jednotlivých oblastí na konkrétní aktuální úroveň, které v rámci venkovní výuky dosahují. Při opakovaném vyplnění tohoto sebehodnoticího dotazníku si učitelé postupně osvojují autory připravený směr rozvoje a sledují svůj postup $\mathrm{v}$ oblastech kontinua. Materiál směřuje pedagogickou práci k pravidelné celoroční venkovní výuce, která je nedílnou součástí rozvrhu. Vede k vytvoření vybavení a zázemí pro venkovní výuku. Posouvá roli učitele přes vedoucího, který nabízí pestré praktické úkoly, ve kterých se zapojují tělo, smysly, zkušenosti, aktivita i rozhodování, až k cílové pozici průvodce předávajícího zodpovědnost zkušeným dětským týmům. Ve vztahu k okolí školy Kontinuum žáky a učitele $\mathrm{v}$ rámci venkovní výuky směřuje $\mathrm{k}$ péči a zájmu o širší okolí školy a jeho rozvoji. Vede k široké podpoře venkovního pobytu dětí a učitelů v hodinách i o přestávkách, v rámci činnosti družiny nebo pro účely zájmových kroužků. Zdůrazňuje význam sdílení zkušeností z venkovní výuky mezi učiteli a společného plánování venkovní výuky při současném rozvíjení interdisciplinární výuky. V rámci hodnocení podporuje prvky formativního hodnocení, vrstevnického hodnocení, sebehodnocení a společného hodnocení a plánování učení. Aktuálně je $\mathrm{k}$ dispozici novější, mírně modifikovaná verze nazvaná Mapa rozvoje, která zahrnuje celkem deset oblastí a disponuje jemnější osmibodovou sebehodnoticí škálou (Ucimesevenku.cz, 2020). 
Venkovní výuka: Metodika pro učení přírodou (Kříž et al., 2019) je metodická příručka, kterou vydala Lipka - školské zařízení pro environmentální vzdělávání Brno. Nabízí model strukturovaného, dlouhodobého a mnohovrstevného učení v přírodě a je doporučena pro 4.-7. ročník základní školy. Metodika vychází z konstruktivistického př́ístupu ke vzdělávání, ve kterém je edukant „vnímán jako ten, kdo své poznání aktivně konstruuje“ (s. 8). Učitel při něm hraje roli zprostředkovatele - facilitátora, který vlastní řídící roli přesouvá na žáky (Nezvalová et al., 2010). Metodika využívá třífázový model učení EUR - evokace, uvědomění, reflexe (Hausenblas \& Koštálová, 2006). Popis fází daného modelu představuje hlavní část metodického materiálu, na niž navazují př́́klady s konkrétními aplikacemi modelu do praxe. Metodický materiál kromě jmenovaného pracuje s postupy a prvky místně zakotveného učení (Skoupá, 2015), badatelsky orientovaného vyučování (Nezvalová et al., 2010) a souvislostního učení (Máchal, 2000).

Koncepce terénní výuky pro základní školy: Na př́kladu námětů pro krátkodobou a střednědobou terénní výuku vlastivědného a zeměpisného učiva (Svobodová et al., 2019b) představuje metodický materiál zaměřený na zavádění koncepční terénní výuky na základních školách. Přestože se materiál podtitulem vztahuje ke geografické tematice, poskytuje obecněji využitelné strategie přenositelné do praxe např́ič různými pojetími vzdělávání na jednotlivých školách u nás. Role učitele se v daném pojetí proměňuje z poskytovatele na zprostředkovatele znalostí a role žáka z pasivního př́ijemce informací na aktivně se učícího jedince (Oost et al., 2011). „Po absolvování vhodně koncipované terénní výuky na základní škole by pak měli být studenti na střední škole schopni pracovat samostatně a badatelsky." (Svobodová et al., 2019b, s. 11).

\section{Jednotící prvky současného směru venkovní výuky}

Na základě vysledování jednotících prvků výše popisovaných materiálů je do jisté míry možné zhodnotit aktuální směřování české venkovní výuky z hlediska vzdělávacích teorií. Popisovaný cílový stav venkovní výuky vytyčený $\mathrm{v}$ rámci metodických materiálů navazuje na myšlenky obsažené $\mathrm{v}$ personalistických teoriích (Bertrand, 2000). Nápadné jsou zejména prvky zdůrazňující roli učitele jako průvodce vzděláváním, které jsou charakteristické pro otevřenou pedagogiku: „posunutí role učitele z pozice nositele informací do pozice průvodce žáků procesem učení“ (Kř́iž et al., 2019, s. 12); „Venku mám 
častěji roli pozorovatele a průvodce než jen vedoucího, který řídí všechen čas" (Ucimesevenku.cz, 2020). Paré (1977) uvádí jako primární hodnoty otevřené pedagogiky autonomii a svobodu a v návrhu otevřené školy zdůrazňuje aktivní žákovu činnost, přijetí žáka jakožto osoby, budování pozitivního obrazu sebe samého, učitele jako partnera a průvodce a hodnocení pojímané jako nástroj zpětnovazební informace. $V$ rámci nedirektivního př́stupu také C. R. Rogers zastává názor, že hlavním zdrojem aktivity jedince je jedinec sám (Bertrand, 2000).

Jednotící prvek analyzovaných materiálů představují dále konstruktivistické rámce prvotně vycházející z prací J. Piageta a G. Bachelarda (Bertrand, 2000; Maňák, 1998) a zdůrazňování prvků aktivního učení (Bonwell \& Eison, 1991). Charakteristické jsou v metodických materiálech zejména aktivní role edukanta v procesu učení a posun učitele do role facilitátora (Nezvalová et al., 2010), což, jak již bylo uvedeno, zároveň koresponduje v tomto aspektu s personalistickými principy: „Učení venku beru jako př́ležitost předat zodpovědnost za učení dětem“ (Ucimesevenku.cz, 2020). „... role žáka se proměňuje z pasivního př́ijemce informací na aktivně se učícího jedince“ (Svobodová et al., 2019b, s. 11). Amonašvili (1987) zdůrazňuje význam pozitivního klimatu při vzdělávání (napřr využívání tzv. blízké zkušenosti dítěte, práce se spontánními prekoncepty žáků, kooperativně laděné činnosti, samostatná práce ve výuce, projekty), protože umožňuje učiteli vtahovat dítě do procesu hodnocení a dávat mu prostor pro sebehodnocení. Vyjmenované charakteristiky jsou společnými znaky aktuálního pojetí venkovních forem výuky. Amonašviliho koncepce se přitom opírá o psychologickou teorii L. S. Vygotského, která vznikala již ve 30 . letech 20 . století. Ve vývoji dítěte Vygotskij rozlišuje dva aspekty - zónu aktuálního vývoje dítěte a zónu nejbližšího vývoje. Svou koncepcí potvrzuje sociální povahu vývoje jedince, jeho závislost na charakteru výchovy, výuky, komunikace, spolupráce, tj. potvrzuje, že se vývoj a učení dají řídit. V pedagogickém kontextu to znamená, že pedagog „musí působit nikoli v zóně aktuálních úrovní vývoje, ale vycházeje z nich, musí vyvolávat a uvádět do pohybu ty psychické síly dítěte, které se ještě nekonstituovaly, ale jsou v zónách nejbližšího vývoje“ (Vygotskij, 1976).

Dalším zachytitelným východiskem aktuálních pojetí venkovní výuky jsou sociokognitivní teorie, konkrétně kooperativní učení (Bertrand, 2000). Charakteristická je přítomnost některých určujících prvků, především zdůrazňování př́nosnosti spolupráce mezi žáky, která má nahradit prvky soutěže. Rozmanité sociální situace směřují k osvojení řady sociálních dovedností, 
například tolerance, přesného formulování vlastních myšlenek, schopnosti přijmout druhé lidi aj. (Augustine et al., 1990).

V současném pojetí venkovní výuky je patrný také odraz myšlenek sociálních teorií, konkrétně pedagogiky osvobození (Bertrand, 2000). Pedagogiku osvobození charakterizuje Shor (1992). Zdůrazňuje význam participace a tvrdí, že participace nemá své místo jen ve třídě, ale všude ve společnosti. Upozorňuje, že učení je kromě procesu kognitivního také procesem afektivním, a v tom kontextu uvádí nutnost vytváření pozitivního prostředí pro většinu žáků, nikoli pouze pro žáky úspěšné v tradičním osvojování vědomostí. Dalšími z principů Shorova pojetí, které můžeme vysledovat, jsou demokratizace výuky, badatelské pojetí výuky a také interdisciplinarita. Obecně lze uvést, že v duchu pedagogik probouzejících uvědomění (Bertrand, 2000) současné pojetí venkovní výuky posiluje vnímavost žáka nebo studenta k jeho roli sociálního činitele. Zejména si pak klade za cíl podporu odpovědného chování $\mathrm{k}$ životnímu prostředí $\mathrm{v}$ dospělosti, ke kterému má být právě čas strávený venku a v prrírodě klíčovou cestou (Daniš, 2016).

Pedagogická teorie se často zabývá otázkou, jak měnit situace ve výuce, aby se žák stal aktivním činitelem, který nejen spolupracuje s učitelem ve vyučovací hodině, ale také se pod vedením učitele zmocňuje nových poznatků. Moderní pedagogické a psychologické teorie chápou proces učení jako přípravu na aktivní a tvořivou činnost, tzn. rozvoj potenciálních vloh a nadání, schopnosti myšlení, jednání, ale i rozvoj schopnosti dále se vzdělávat. Moderní škola předpokládá maximální rozvíjení aktivity žáka a jeho samostatnosti, zodpovědnosti a také schopnosti samostatně regulovat svoji činnost, a podílet se tak na svém kognitivním i osobnostním rozvoji (Šikulová, 2009). Helus $(2004,2008)$ vznáší požadavky na proměnu vzdělávání, když mluví o společnosti vědění a společnosti obratu a její edukační kultuře. Podle Lukáškové (2010) bychom se v pohledu na vzdělávání měli vyvarovat všech jednostranností a uplatňovat holistický pohled na vzdělávání. Nové možnosti nám v tomto směru ukazuje venkovní pedagogika právě v preferovaných přístupech, kterými je aktuálně u nás směrována. Venkovní výuka je pro školy cestou k vytváření holistického vzdělávacího prostředí (Skaugen \& Fiskum, 2015). Rickinson a kol. (2004) v rámci jednoho z klíčových výstupů své rozsáhlé metastudie věnované venkovní výuce ve Velké Británii uvádí, že dobře koncipovaná, přiměřeně naplánovaná a dobře vedená venkovní výuka nabízí studentům př́ležitosti k rozvoji jejich znalostí a dovedností nad rámec 
každodenní zkušenosti ze školní třídy. Budiž to závěrem bráno jako vyjádření určité naděje $\mathrm{v}$ rámci budoucího vývoje tohoto segmentu vzdělávání v českých zemích.

\section{Závěr}

Z předložených indicií je možné nastínit do jisté míry konkrétnější obraz současného stavu venkovní výuky v České republice, přestože, jak již bylo výše naznačeno, mnoho důležitých informací pro korektnější charakteristiku tématu stále schází. Venkovní výuka je realizována nejčastěji krátkodobě a spíše občasně, především ve školních zahradách a blízkém okolí škol; na úrovni základní školy nejvíce $v$ rámci vzdělávací oblasti člověk a svět práce, dále v oblastech člověk a příroda, člověk a zdraví, člověk a jeho svět, umění a kultura a při řešení prưřezových témat. Velká většina škol má školní zahradu k dispozici a alespoň částečně ji pro venkovní formy výuky využívá. Většina škol má ve svých kurikulárních dokumentech zahrnutou venkovní výuku ve formě exkurzí, vycházek, terénních cvičení, školních výletů, sportovních kurzů a dalších sportovních aktivit. Dalšími oblastmi, ve kterých se venkovní výuka uplatňuje, jsou školy v př́rodě, adaptační kurzy, projektová výuka, zvláště pak s akcentem na místně zakotvené učení a komunitu. Rychle rostoucí vliv na podobu a rozsah venkovní výuky u nás mají v současnosti také centra environmentálního vzdělávání, která se zaměřují jak na realizaci konkrétních programů pro školy, tak na vzdělávání a rozvoj pedagogů v daném segmentu a značně přispívají k rozšiřování venkovních forem výuky v českém prostředí.

Venkovní formy výuky se v posledních letech v České republice dostávají do širšího povědomí pedagogické veřejnosti a jsou s rostoucí měrou využívány $\mathrm{v}$ rámci všech úrovní vzdělávání. Jakkoli není k dispozici dostatečné množství informací, které by mohly probíhající trendy podrobněji dokumentovat, alespoň částečné indicie ukazují, že zájem o venkovní výuku narůstá. Na její popularizaci a určitém směřování přístupů se do velké míry podílí i vzdělávací centra akcentující a dlouhodobě využívající ve své praxi právě venkovní výuku. Na základě analýzy tři metodických dokumentů byly zjištěny jednotící prvky, s jejichž pomocí je do jisté míry možné charakterizovat aktuální směřování venkovní výuky u nás. Pojetí konkretizovanější podoby venkovní výuky, k němuž metodické materiály vedou, v sobě nese prvky otevřené pedagogiky ve smyslu posilování role učitele jako partnera a průvodce žáka 
aktivním učením a zdưrazňuje nutnost aktivní role žáka při edukačním procesu. V té souvislosti jsou pro toto pojetí charakteristické konstruktivistické rámce a badatelsky orientované přístupy. Aktuální pojetí venkovní výuky zdůrazňuje př́nosy kooperativního učení a vede, v duchu pedagogik probouzejících žákovo uvědomění, k odpovědnosti za životní prostředí. Výše charakterizovaná aktuální pojetí venkovních forem výuky do značné míry naplňují koncepty holistického pojetí výuky.

\section{Autoři}

Mgr. Karel Nepraš, Univerzita Jana Evangelisty Purkyně v Ústí nad Labem, Pedagogická fakulta, Katedra preprimárního a primárního vzdělávání, Hoření 13, 40096 Ústí nad Labem, e-mail: carlinepras@seznam.cz

doc. PhDr. Renata Šikulová, Ph.D., Univerzita Jana Evangelisty Purkyně v Ústí nad Labem, Pedagogická fakulta, Katedra preprimárního a primárního vzdělávání, Hoření 13, 40096 Ústí nad Labem, e-mail: renata.sikulova@ujep.cz

\section{Literatura}

Amonašvili, Š. A. (1987). Výchovná a vzdělávací funkce hodnocení ve vyučování žáků. Pedagogická fakulta Univerzity Karlovy.

Augustine, D., Gruber, K., \& Hanson, L. (1990). „Cooperation works!“. Educational Leadership, 47(4), 4-7.

Baueršímová, S. (2007). Stav školních zahrad při základních školách v České republice. In K. Burešová (Ed.), Učíme se v zahradě (s. 63-70). Chaloupky o.p.s., školská zařízení pro zájmové a další vzdělávání.

Bertrand, Y. (2000). Soudobé teorie vzdělávání. Mladá fronta.

Bonwell, C. C., \& Eison, J. A. (1991). Active learning: Creating excitement in the classroom. AsheEric Higher Education Reports.

Cottrell, J. R., \& Cottrell, S. P. (2020). Outdoor skills education: What are the benefits for health, learning and lifestyle? World Leisure Journal, 62(3), 219-241. https://doi.org/10.1080/16 078055.2020 .1798051

Činčera, J., \& Havlíček, F. (2016). Centra environmentálního vzdělávání z pohledu učitelů. Envigogika, 11(2), 1-14. https://doi.org/10.14712/18023061.534

Činčera, J., \& Holec, J. (2016). Terénní výuka ve formálním vzdělávání. Envigogika, 11(2). https:// doi.org/10.14712/18023061.533

Činčera, J., Jančaříková, K., Matějček, T., Šimonová, P., Bartoš, J., Lupač, M., \& Broukalová, L. (2016). Environmentální výchova z pohledu učitelů. BEZK, z. s.; Fakulta sociálních studií; Masarykova univerzita; Agentura Koniklec, o. p. s. 
Činčera, J., Králíček, I., Bílek, M., Loudová, I., Machková, V., Musílek, M., Štindl, P., Švarcová, E., \& Vízek, L. (2019). Výuka ve venkovním prostredí. Metodický text pro studenty učitelství. Gaudeamus.

Daniš, P. (2016). Děti venku v př́rodě: ohrožený druh? Ministerstvo životního prostředí.

Daniš, P. (2018). Tajemství školy za školou: Proč učení venku v přírodě zlepšuje vzdělávací výsledky, motivaci a chování žákủ. Ministerstvo životního prostředí.

Danišová, J. (2018). Družiny venku. Vzdělávací centrum TEREZA, z. ú.

Danišová, J. (2019). Dny, které táhnou ven. (Nejen) družiny venku 2. Vzdělávací centrum TEREZA, z. ú.

Dillon, J., Rickinson, M., Teamey, K., Morris, M., Choi, M., Y., Sanders, D., \& Benefield, P. (2006). The value of outdoor learning: Evidence from research in the UK and elsewhere. School Science Review, 87(320), 107-111.

Green Schoolyards America. (2018). Měsíc školních zahrad 2018 - Průvodce aktivitami venku. International School Grounds Alliance / Nadace Proměny Karla Komárka.

Hausenblas, O., \& Koštálová, H. (2006). Co je E-U-R: Podrobněji k evokaci. Kritické listy, 6(22), $54-58$.

Helus, Z. (2004). Dítě v osobnostním pojetí. Obrat $k$ dítěti jako výzva a úkol pro učitele i rodiče. Portál.

Helus, Z. (2008). Teoretická východiska pojetí učitele v době měnících se nároků na školu a vzdělávání. In V. Spilková \& J. Vašutová (Eds.), Učitelská profese v měnících se požadavcích na vzdělávání (s. 11-28). Pedagogická fakulta Univerzity Karlovy.

Hofmann, E., Korvas, P., Poláček, P., et al. (2009). Multimediální učebnice pro terénní výuku. Masarykova univerzita. https://is.muni.cz/do/rect/el/estud/pedf/js09/teren/web/ index.html

Hofmann, E., Trávníček, M., \& Soják, P. (2011). Integrovaná terénní výuka jako systém. In T. Janík, P. Knecht, \& S. Šebestová (Eds.), Smíšený design v pedagogickém výzkumu: Sborník př́spěvků z 19. výroční konference České asociace pedagogického výzkumu (s. 310-315). Masarykova univerzita.

Chaloupky o.p.s., školská zařízení pro zájmové a další vzdělávání. (2020). Chaloupky 2019. Učíme reči prírody [výroční zpráva].

Chmelová, Š., Ryplová, R., Vácha, Z., Vaněčková, O., \& Procházka, M. (2019). Školní zahrady středních škol a jejich potenciál pro environmentální výchovu. Envigogika, 14(1), 1-20.

Jančaříková, K. (2007). Myšlenka vyučování pod širým nebem má v českých zemích tradici. In K. Burešová (Ed.), Učíme se v zahradě (s. 17-18). Chaloupky o.p.s., školská zařízení pro zájmové a další vzdělávání.

Kolektiv (2014). Mapy učebního pokroku. Obecná metodika. www.scio.cz, s.r.o. https://mup.scio. cz/Content/Files/Metodika_obecna.pdf

Komenský, J., A. (1930). Didaktika velká. Dědictví Komenského.

Kovářová, J. (2014). Návrh úpravy školní zahrady Fakultní základní školy dr. Milady Horákové a Mateřské školy Olomouc (Bakalářská práce). Univerzita Palackého v Olomouci.

Kř́íz, M., Mikulicová, H., Nešpor, J., Pitelková, P., \& Vorlíček, J. (2019). Venkovní výuka. Metodika pro učení přírodou. Lipka - školské zařízení pro environmentální vzdělávání Brno, příspěvková organizace. 
Lambert, D., \& Balderstone, D. (2010). Learning to teach geography in the secondary school: A companion to school experience. Routledge.

Lambert, D., \& Reiss, M. J. (2014). The place of fieldwork in geography and science qualifications. Institute of Education, University of London.

Lesnims.cz $(2019,12$. června). Historie lesních MŠ. https://www.lesnims.cz/lesni-ms/historielesnich-ms.html

Lipka - školské zařízení pro environmentální vzdělávání, Brno, příspěvková organizace (2020). Výroční zpráva Lipky 2019.

Lukášová, H. (2010). Kvalita života dětí a didaktika. Portál.

Máchal, A. (2000). Průvodce praktickou ekologickou výchovou (metodická příručka pro začínající učitele a pedagogické pracovníky stredisek ekologické výchovy). Rezekvítek Brno ve spolupráci s Lipkou - Domem ekologické výchovy Brno.

Maňák, J. (1998). Rozvoj a ktivity, samostatnosti a tvořivosti žáků. Pedagogická fakulta Masarykovy univerzity.

Masarykova univerzita. (2020,12. prosince). Systém terénní výuky pro základní školy. Informace o projektu. https://www.muni.cz/vyzkum/projekty/38644

Masters, G., \& Foerster, M. (1996). Progress maps, assesment ressource kit. The Australian Council for Educational Resarch Ltd.

Miller, B. G. (2017). Outdoor learning. In K. Peppler, The SAGE encyclopedia ofout-of-school learning (s. 560-561). SAGE Publications, Inc. http://dx.doi.org/10.4135/9781483385198.n216

Ministerstvo školství, mládeže a tělovýchovy (2018). Rámcový vzdělávací program pro předškolní vzdělávání (úplné znění k 1. lednu 2018).

Ministerstvo životního prostředí $(2020,13$. ledna). NPŽP - výzva č. 7/2019: Př́rodní zahrady. https://www.mzp.cz/cz/npzp_072019_prirodni_zahrady

Morkes, F. (2002). Kapitoly o školství, o ministerstvu a jeho predstavitelích. Pedagogické Muzeum J. A. Komenského.

Morkes, F. (2010). Z historie školních zahrad. Envigogika, 5(2).

Nepraš, K. (2020, 5. listopadu). Postoje českých učitelů $k$ venkovní výuce (Poster). ProjectBased education and other activating strategies in science education XVIII. International conference. Praha, Česká republika.

Nezvalová, D., Bílek, M., \& Hrbáčková, K. (2010). Inovace v přírodovědném vzdělávání. Univerzita Palackého v Olomouci.

Oost, K., De Vries, B., \& Van der Schee, J. A. (2011). Enquiry-driven fieldwork as a rich and powerful teaching strategy - school practices in secondary geography education in the Netherlands. International Research in Geographical and Environmental Education, 20(4), 309-325. https://doi.org/10.1080/10382046.2011.619808

Paré, A. (1977). Créativité et pedagogie ouverte. Éditions NHP.

Předotová, D. (2014). Historie školství od roku 1945 do současnosti (Bakalářská práce). Filozofická fakulta Univerzity Palackého v Olomouci.

Rickinson, M., Dillon, J., Teamey, K., Morris, M., Choi, M. Y., Sanders, D., \& Benefield, P. (2004). A review of research on outdoor learning. Field Studies Council.

Rohlena, V. (1928). Školy v prírodě. Praha.

Shor, I. (1992). Empowering education. Critical teaching of social change. University of Chicago Press. 
Skaugen, R., \& Fiskum, T. A. (2015). How schools with good academic results justify their use of outdoor education. International Education Research, 3(4), 16-31. http://dx.doi. org/10.12735/ier.v3i4p16

Skoupá, L. (2015, 2. listopadu). Místně zakotvené učení a questové trasy. Metodický portál RVP. https://clanky.rvp.cz/clanek/c/Z/20437/mistne-zakotvene-uceni-a-questove-trasy.html/

Svobodová, H., Durna, R., Pernica, M., \& Hofmann, E. (2018). Námětovník pro terénní výuku socioekonomické geografie (školní pozemek, město, venkov). Masarykova univerzita. https:// is.muni.cz/do/rect/el/estud/pedf/js18/nametovnik/web/index.html

Svobodová, H., Durna, R., Mísařová, D., \& Hofmann, E. (2019a). Komparace ukotvení terénní výuky ve školních vzdělávacích programech a její pojetí v modelových základních školách. Orbis scholae, 13(2), 95-116.

Svobodová, H., Mísařová, D., Durna, R., Češková, T., \& Hofmann, E. (2019b). Koncepce terénní výuky pro základní školy. Na př́kladu námětů pro krátkodobou a střednědobou terénní výuku vlastivědného a zeměpisného učiva. Masarykova univerzita. https://doi.org/10.5817/ CZ.MUNI.M210-9246-2019

Šikulová, R. (2009). Žák jako aktivní subjekt výchovně vzdělávacího procesu. In J. Škoda, P. Doulík et al., Aktuální problémy vybraných oborových didaktik (s. 71-103). Univerzita Jana Evangelisty Purkyně v Ústí nad Labem.

Špačková, B. (2013). Environmentální výchova ve školní zahradě mateřské školy (Bakalářská práce). Masarykova univerzita.

Štorch, E. (1929). Dětská farma, eubiotická reforma školy. Vydavatelský odbor Ústředního spolku jednot učitelských, Brno.

TEREZA, vzdělávací centrum, z. ú. (2020a). Jdeteven!cz. https://jdeteven.cz/cz

TEREZA, vzdělávací centrum, z. ú. (2020b). Výroční zpráva 2019. https://terezanet.cz/_files/ userfiles/vyrocni_zpravy/TEREZA_vyrocni_zprava_2019_stredni.pdf

Ucimesevenku.cz (2019, 3. prosince). Cesta ven, aneb kontinuum pro rozvoj učení venku. https:// ucimesevenku.cz

Ucimesevenku.cz (2020, 14. prosince). Učíme se venku. https://ucimesevenku.cz

Václavík, V. (2002). Organizační formy výuky. In Z. Kalhous \& O. Obst et al., Školní didaktika (s. 293-306). Portál.

Vácha, Z. (2015). Didaktické využití školních zahrad v České republice na primárním stupni základních škol. Scientia in educatione, 6(1), 80-90.

Vaníček, V. (1875). Vyučování pod širým nebem. Posel z Budče, VI: 344, 442.

Veselá, A., Leischnerová, M., Halúzová, J., \& Kolářová, V. (2019). Ekoturistická kancelář s. r. o. (metodika). Lipka - školské zařízení pro environmentální vzdělávání, p. o.

Vygotskij, L. S. (1976). Vývoj vyšších psychických funkcí. Státní pedagogické nakladatelství. 


\title{
Where does outdoor education come from and where does it go? History, present and trends in outdoor education in the context of educational theories
}

\begin{abstract}
The popularity of outdoor education has been growing in the Czech Republic in recent years. The status of outdoor education therefore deserves more attention because as the use of outdoor education increases, so does its impact on the educational process. Outdoor education in Czech primary schools is based on the tradition of using the school surroundings and school gardens. Its roots go back to the $19^{\text {th }}$ century. Currently, it is mostly implemented on a short-term and rather occasional basis. Most schools have a school garden and use it at least partly for outdoor education. Schools have included excursions, walks, fieldwork, school trips, sports courses, outdoor schools, adaptation courses and project-based learning in their curriculum documents. Environmental education centres are now having a rapidly growing influence on the shape and scope of outdoor education in our country. They focus on the implementation of programmes for schools, teacher training and development, and contribute significantly to the expansion of outdoor forms of learning. Common features can be identified in current methodological documents on outdoor education. The methodological materials lead to outdoor education, which carries elements of open education in the sense of strengthening the role of the teacher as a partner and guide of the pupil through active learning and emphasizes the need for an active role of the pupil in the educational process. Constructivist frameworks and inquiry-based approaches are characteristic of the current direction of outdoor education. The benefits of cooperative learning and awakening environmental responsibility are highlighted. Current concepts of outdoor education largely fulfil the concepts of holistic learning.
\end{abstract}

Keywords: outdoor education, outdoor learning, fieldwork, educational theories 